\section{Why We Talk About Race}

\section{S. Joshua Swamidass (D)}

https://doi.org/10.54739/hj8a

he news cycle on MLK day came and went. We did not publish an article on race here, but I did publish one at The Panda's Thumb. Dr. Martin Luther King Jr. remains an important voice for our current moment. The questions of race, also, are tightly connected to our mission. A few days later, I am still thinking about the questions of race, and the legacy of MLK.

As we think about evolution and creation, about inheritance and justice, we cannot avoid the topic of race. Good and bad, for better and for worse, race is interwoven through the historical conversation on origins. The first theories of race, after all, began as theories of origins.

Race concerns our ancestry, and science speaks to our ancestry as well. Science certainly has information to add, but the questions of race call us beyond a science-only view of the world.

\section{Moving Beyond Science}

In truth, I have been thinking about race quite a bit over the last several years. Back in 2017, one of the most intense Veritas Forums I attended, at Delaware University, brought us to the questions of race. We were asked, "Is There Truth Beyond Science?"

I confided a story with the students. The fall of 2017, in the shadow of Ferguson, I gathered with seminary professors and friends in Saint Louis. On a monthly basis, we met to discuss Dr. King's sermons and writings at Concordia Seminary. Some of our first readings were The Ethical Demands for Integration and Paul's Letter to the American Christian.

Just two weeks after our first meeting, the Stockley Verdict was announced, and a police officer was acquitted. The streets outside my home exploded in protest. I walked onto Delmar Boulevard at night, unprepared for what I saw. My scientific training was worthless for the moment.

On the street, watching the clash between non-violent protesters and the police, the scientist finds his limits. We should certainly hope there is truth beyond science. Science can neither name nor end injustice.

At that Delaware Veritas Forum, my discontent spilled out onto the stage. I was reminded why Dr. King chose to study theology.

But America, as I look at you from afar, I wonder whether your moral and spiritual progress has been commensurate with your

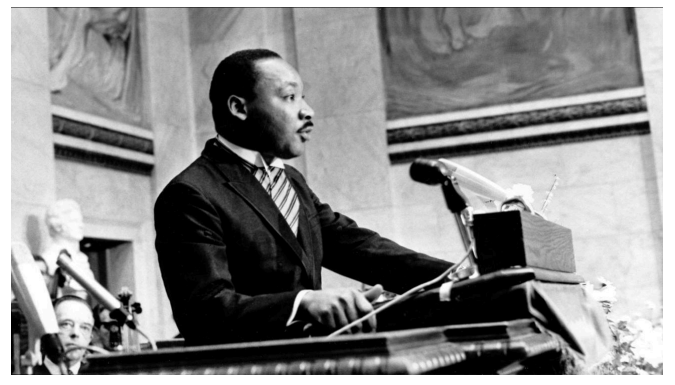

scientific progress. It seems to me that your moral progress lags behind your scientific progress...

MLK, Paul's Letter to the American Christian ( video and written)

When Dr. King was decided to go graduate school, he was searching for resources with which to make sense of the segregated world. He found these resources in theology, not science.

We discussed this with the students. I stayed out late with them and we grieved the reality of our segregated world. We wondered about the One who is greater than science. We long for the beauty of the Kingdom of God.

This year, in Fall of 2020, this exchange was still on my mind. I offered some thoughts to the college students coming back to campus during a pandemic:

Martin Luther King, maybe just a bit over 50 years ago, he marched and he talked about the kingdom of God. He prayed Jesus's prayer, that God's kingdom, heaven, would be here on earth in the same way that it's in heaven, that His Will would be done in both places...

In our world, where things are just broken...we have an opportunity to to invite something better...to long for it, to beg for it, to cry for it, to mourn for it, knowing that there really is that better way.

Let's go pursue it together, knowing that God doesn't just want us to long for heaven, He wants us to long for heaven on earth.

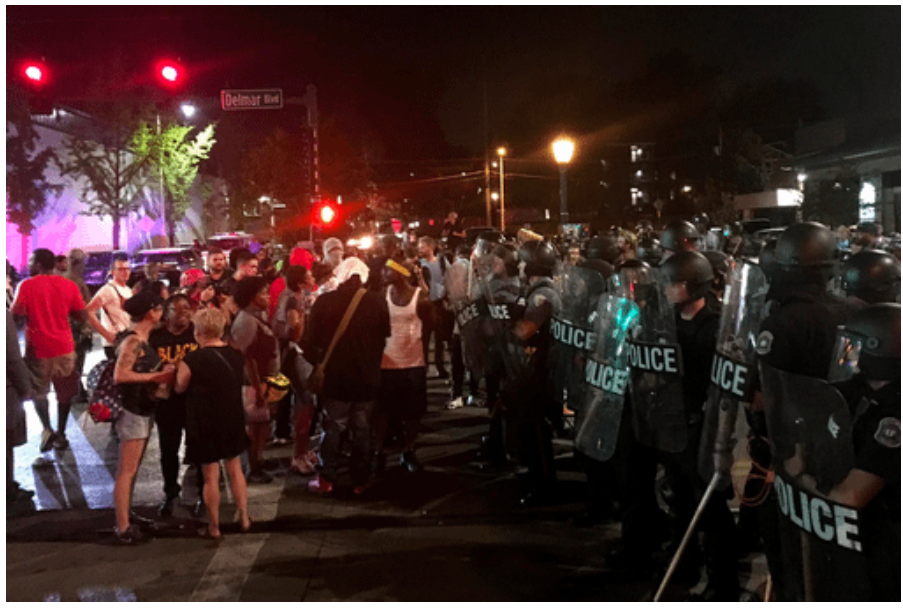

This photo was taken by a journalist on Delmar Blvd., the night I walked to see the Stockley Verdict protests. 
Students give me a great deal of hope. They know that this world is broken. They want something better. They are looking for a better way.

I am certain they will do better than the generation before them. This should give us all a great deal of hope. Science has an important role in the conversation, but they also seek the Kingdom of God.।

\section{Why Race is Difficult}

The questions of race are difficult. They are difficult, in large part, because race matters. The questions here invite us to learn and examine our history, and that of our ancestors. They cause us question our identities, and how we see and treat one another. They might even undermine our politics and unsettle our certainty of goodness.

This difficulty is often exploited. In our work at Peaceful Science, commonly we have dealt with ungrounded accusations of racism. Often, this has been a type of "race baiting," where spurious concerns about racism are raised, so as to distract from legitimate scientific concerns.

Race baiting is exceedingly effective because race is difficult to talk about. Still, as difficult as it is, the questions of race thrust us headlong into the grand question, causing us to ask: what does it mean to be human?

At our best, we responded to race-baiting by reckoning our history, rehumanizing the dehumanizing reality of the world.

I learned about Ota Benga, a man from Africa displayed at the St. Louis Zoo at the 1904 World's Fair, walking distance from my home. Years later, he committed suicide. He was stranded here, and could not cobble together the money needed to go home to his family in Africa.

His experience as human in a zoo was disgustingly dehumanizing. Our memory of him, in entering into grief about his loss, we cannot undo what was done. We can, however, take small steps to rehumanizing him.

In remembering him, in grieving what was done and what was lost, we are in fact rehumanizing ourselves.

\section{What if Racism is Common, but forgivable?}

A month ago, we published an article that featured a picture of Victoria, my wife, with me. It was one of our engagement photos.

Someone on facebook responded negatively. His comment displayed confusion about how genetics works, and opposition to interracial marriage. I cannot judge the private intentions of his heart, but it really looked racist. Adding some insult to the injury, he proceeded to instruct me on the genetics of race, complaining of an appeal to authority when gently I tried to clarify the science for him. Then, he blocked me!

There was a curiously large outpour of sympathy on social media. Victoria and I appreciate the well wishes, but it was also a bit odd. Most well-wishers, it seemed, thought that racism like this is both rare and unforgivable. See this note from a scientist,
I am speechless. There are a lot of things we all might expect when we try to speak into the space between science and our Christian faith, but this should not be one of them.

Receiving this email was hard. In the past, this particular scientist had turned a blind eye to racist comments about me. Rather than sympathy for an anonymous facebook comment, I would have preferred acknowledgement from him of the racist comments by his own community first.

There might be some comfort in understanding racism as rare and unforgivable. We can confidently make displays of righteous indignation against racism, while keeping blind to how we ourselves have made mistakes.

This fiction might be comfortable at times, but it paints us into a corner too. If racism is so rare and unforgivable, we cannot allow ourselves to acknowledge when we ourselves have made mistakes. When mistakes are made, we will struggle to truthfully see our own actions, history and community.

The thing is, racism is exceedingly common. Victoria and I have dealt with racist comments many times, and it is most difficult when it touches on our children. My credentials as a scientists are regularly dismissed by non-experts. Yes disregard of expertise is common online, but it has happened to me in ways I do not see take place with scientists that are not minorities.

Racism is common, but there is good news. Racism is also forgivable.

I am reminded of my own mistakes here, and when I have been forgiven. Others have been forgiven too. I am reminded of Daryl Davis, who talked $200 \mathrm{KKK}$ members out of their robes. If forgiveness is possible for the klansman, it certainly is possible in the racism that is far more common.

Racism really is far more common than we might expect, but also it is forgivable.

\section{Why We Talk About Race}

There is so much more to write about here. So much more to expand upon and explain. In time, I am sure we will.

Do not be afraid. Some readers may disagree, even, with many of the things I have written here. Some might wish we just avoided this topic

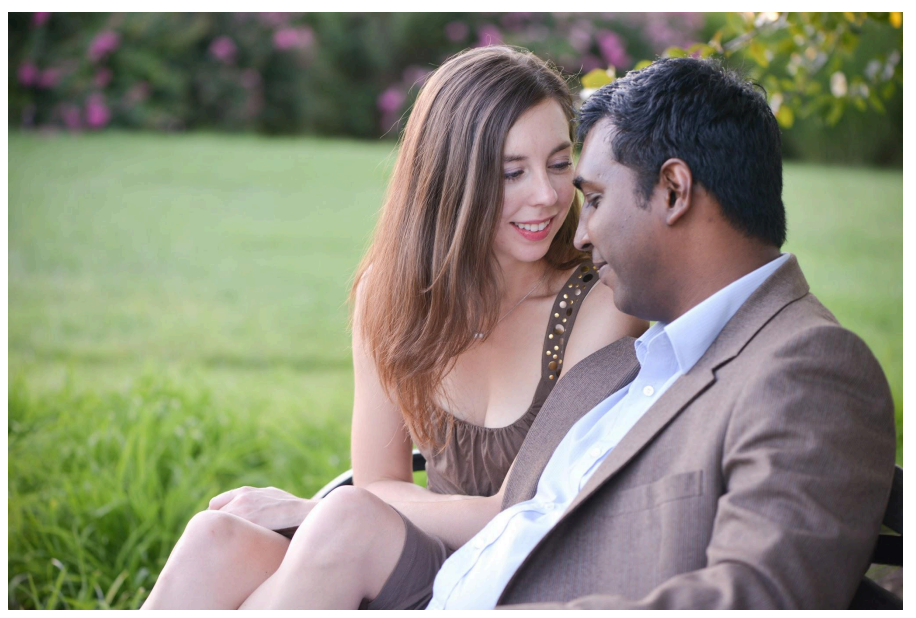


altogether. These injuries are real, and the disagreements are to be expected. Just like the debate on origins, the debates about race have been dehumanizing for all of us.

Still, we will talk about race.

The reason the conversations about race are so difficult is because they matter. It is our mission to seek understanding across these disagreements, and to find community that does not require agreement. Science is not enough, but it does have information that can help us too.

A better way is in view. We can't find it alone, but perhaps we can together.

It is very fitting that this article did not come out on MLK day, a day when everyone pauses to remember the Civil Rights movement. For us, the questions of race are not just about the news cycle.

\section{References}

http://pandasthumb.org/archives/2021/01/questions-raceevolution.html

https://discourse.peacefulscience.org/t/_/137

https://en.wikipedia.org/wiki/Ferguson_unrest

http://www.faculty.umb.edu/lawrence_blum/courses/318_11/readings/ king_ethical_demands.pdf

https://kinginstitute.stanford.edu/king-papers/documents/pauls-letteramerican-christians-sermon-delivered-dexter-avenue-baptistchurch

https://www.stltoday.com/news/local/iconic-images-video-followingnot-guilty-verdict-in-jason-stockley-trial

https://www.youtube.com/watch?v=7p5iOhXumaQ
For us, the questions of race are more closely connected to our mission. We seek encourage conversation around the grand question of what it means to human. At all times of the year, on MLK day or not, the conversation about race brings us to this grand question.

The conversation is interesting and engaging, but it can be difficult, so we have to practice humility, tolerance, and patience. Ironically, approaching the must dehumanizing of conversations can be hopeful. Finding a better way here can humanize all of us. We could experience something of the Kingdom of God, that "beloved community" of which MLK so often spoke.

In the end, we seek peace in this conflict too. This is why we talk about race.

https://discourse.peacefulscience.org/t/a-message-for-collegestudents-in-fall-2020

https://discourse.peacefulscience.org/t/_/13054

https://discourse.peacefulscience.org/t/_/1568

https://peacefulscience.org/articles/why-i-went-public-evolution/

https://discourse.peacefulscience.org/t/_/12618

https://discourse.peacefulscience.org/t/_/5592

https://peacefulscience.org/about/mission-and-values/

https://peacefulscience.org/articles/definition-race/

https://peacefulscience.org/articles/inazu-humility-tolerance-patience/ 